\title{
USE OF CASHEW BARK EXUDATE GUM IN THE PREPARATION OF 4 \% LIDOCAINE HCL TOPICAL GELS
}

\author{
M. SAQUIB HASNAIN ${ }^{1}$, POONAM RISHISHWAR ${ }^{1 *}$, SADATH ALI ${ }^{2}$ \\ ${ }^{1}$ Department of Pharmacy, Shri Venkateshwara University, NH-24, Rajabpur, Gajraula, Amroha 244236, U. P., India, ${ }^{2}$ Department of \\ Pharmacy, Glocal University, Saharanpur 247001,U. P., India \\ Email: prishishwar@gmail.com
}

Received: 09 May 2017 Revised and Accepted: 19 Jun 2017

\begin{abstract}
Objective: The objective of the current work was to prepare and evaluate ex vivo skin permeation of cashew bark exudate gum based $4 \%$ lidocaine $\mathrm{HCl}$ topical gels.

Methods: In the current work, $4 \%$ lidocaine $\mathrm{HCl}$ topical gels were prepared by using different concentrations of cashew bark exudate gum, HPMC $\mathrm{K} 4 \mathrm{M}$, lidocaine $\mathrm{HCl}$, methyl paraben (as preservative) and glycerin (as plasticizer). The formulated topical gels were evaluated for pH, viscosity, and ex vivo skin permeation through excised porcine ear skin membrane.

Results: The pHs of these formulated $4 \%$ lidocaine $\mathrm{HCl}$ topical gels were found within the range of $6.04 \pm 0.02$ to $6.52 \pm 0.04$; whereas, the viscosities were measured within the range, $4.38 \pm 0.02 \times 10^{6}$ to $4.74 \pm 0.04 \times 10^{6} \mathrm{cps}$. Sustained ex vivo permeation of lidocaine was measured over 7 h. Highest ex vivo permeation flux was measured when $0.1 \%$ menthol was incorporated as a permeation enhancer. It was also higher than that of the marketed $4 \%$ lidocaine $\mathrm{HCl}$ topical gel. The stability study by freeze thaw cycle method revealed physically stable gels without the occurrence of syneresis.
\end{abstract}

Conclusion: The results clearly indicate a promising potential of the use of cashew bark exudate gum as a gelling material with HPMC K4M to prepare $4 \%$ lidocaine $\mathrm{HCl}$ topical gels of good skin permeation capability.

Keywords: Cashew bark exudate gum, Gel, Lidocaine $\mathrm{HCl}$, Skin permeation, Topical application

(C) 2017 The Authors. Published by Innovare Academic Sciences Pvt Ltd. This is an open access article under the CC BY license (http://creativecommons.org/licenses/by/4.0/) DOI: http://dx.doi.org/10.22159/ijpps.2017v9i8.19815

\section{INTRODUCTION}

During past few decades', topical drug delivery through the skin has been employed as a safe and effective way to deliver drugs for local and sustained actions [1-6]. As compared to oral drug delivery, it restricts systemic absorption and hepatic metabolism of drugs, avoids the chances of gastrointestinal irritation and also, minimises systemic toxicities [7-9]. The therapeutic effectiveness of topical drug delivery formulations mostly depends on the capability to deliver drugs to the sites of action onto skin surface [9-11]. In general, local anaesthetics are administered through parenteral routes (mainly, intravenous and hypodermic routes) [12]. Only, a few local anaesthetics are applied topically, by the dermatologists and the dentists, mainly [13]. The topical applications of local anaesthetics facilitate some potentia benefits over parenteral routes such as continuous drug delivery, avoidance of systemic side-effects (like hematoma and nerve damages) and thus, improvement of patient compliances [14]. However, the topical delivery of local anaesthetics is associated with some constraints like poor skin permeability and slow skin penetration rates. Therefore, effective topical formulations of local anaesthetics with good skin permeability and rapid skin penetration rates are desperately essential.

Lidocaine is a local anaesthetic, which is employed in the treatment of open skin lesions and sores [15]. It is also employed as a topical local anaesthetic in various small surgical procedures like venipuncture, suturing of wounds, etc [16]. The topical application of lidocaine recommends some potential benefits such as rapid onset of action, minimum systemic toxicity, etc [17]. These benefits favour the topical delivery of lidocaine for local action. In the previous literature, a few topical formulations of lidocaine are reported [18-22]. In the current research, we made an attempt to prepare $4 \%$ lidocaine $\mathrm{HCl}$ topical gels of using cashew bark exudate gum.

Cashew bark exudate gum is a natural polymer extracted from Anacardium occidentale tree, belonging to the family: Anacardiaceae
[23-24]. This plant derived gum molecules are composed of galactose unit-chains of with branches of glucose, arabinose, rhamnose and uronic acid units [25-26]. According to the previous literature, a flurry of the investigation was performed on the utilizations of cashew bark exudate gum as pharmaceutical excipients, such as, tablet binder in paracetamol tablets [27], mucoadhesive in the buccal formulation of curcumin [28] and gelling agent in aceclofenac gel [29]. In the present research, cashew bark exudate gum and hydroxypropyl methylcellulose (HPMC K4M) was employed as a gelling agent in the formulation of lidocaine $\mathrm{HCl}$ topical gels. In vitro skin permeability of lidocaine through the excised porcine ear skin membrane from the formulated $4 \%$ lidocaine $\mathrm{HCl}$ topical gels were also tested and analyzed.

\section{MATERIALS AND METHODS}

\section{Materials}

Lidocaine $\mathrm{HCl}$ (Albert-David Pvt. Ltd., India), HPMC K4M (Loba Chemie Pvt. Ltd., India), menthol (Qualigens Fine Chemicals, India) were used. Cashew bark exudate gum was extracted from the crude exudate of cashew tree bark (collected at Jharpokharia, Odisha, India in the month of September 2015). All the other chemicals and reagents used were of analytical grade and commercially available.

\section{Extraction of cashew gum}

The crude cashew bark exudate was cleaned by removing bark pieces and further extraneous substances. The crude exudate was dried in a tray drier at $50 \pm 2{ }^{\circ} \mathrm{C}$ for $10 \mathrm{~h}$ until it became brittle. The dried exudate was reduced to powder through milling in a domestic blender and then, sieving. $1 \mathrm{~kg}$ of the crude cashew bark exudate powder was dissolved in 2 liter distilled water and the exudate solution was boiled for 1 hour under occasional stirring in a temperature controlled water-bath. After cooling at room temperature, the resulting exudate solution was further cooled by keeping in a refrigerator overnight to settle out proteins and 
undissolved materials, if occurred. The upper solution was decanted and then, concentrated at $50 \pm 2{ }^{\circ} \mathrm{C}$ by a temperature controlled water-bath to $1 / 3^{\text {rd }}$ of its original volume. After cooling the concentrated cashew tree exudate solution at room temperature, it was poured into twice the volume of acetone with continuous stirring. The formed precipitate was filtered and washed repeatedly with acetone. The collected precipitate was dried in a tray drier at $50 \pm 2{ }^{\circ} \mathrm{C}$ for $10 \mathrm{~h}$. The obtained dried film of precipitate was milled to a fine powder of cashew gum and sieved through sieve number 80 . The extracted cashew tree bark exudate gum was kept in an air-tight desiccator until further use.

\section{Preparation of $4 \%$ lidocaine $\mathrm{HCl}$ gels}

$4 \%$ Lidocaine $\mathrm{HCl}$ gels were prepared by using different concentrations of cashew bark exudate gum, HPMC K4M, lidocaine
$\mathrm{HCl}$, methyl paraben (as a preservative) and glycerin (as plasticizer). The formula of $4 \%$ lidocaine $\mathrm{HCl}$ gels is shown in table 1 . The formulated gels were stored in a cool place until further use.

\section{pH determination}

pHs of formulated $4 \%$ lidocaine $\mathrm{HCl}$ gels were determined using a $\mathrm{pH}$ meter (Systronics Instruments, India) by inserting glass electrode into the gel, completely [22].

\section{Viscosity measurement}

Viscosities of formulated $4 \%$ lidocaine $\mathrm{HCl}$ gels were measured using a cone and plate viscometer (Brookfield DV III Ultra V6.0 RV, Brookfield Engineering Laboratories, Middle-boro, MA) at $25 \pm 0.3{ }^{\circ} \mathrm{C}$. Rheocalc V2.6 software was employed for the calculation of viscosities [22].

Table 1: Formulation charts of $4 \%$ lidocaine $\mathrm{HCl}$ topical gels containing cashew bark exudate gum

\begin{tabular}{|c|c|c|c|c|}
\hline \multirow[t]{2}{*}{ Ingredients } & \multicolumn{4}{|c|}{ Formulation codes } \\
\hline & G1 & G2 & G3 & G4 \\
\hline Lidocaine $\mathrm{HCl}(\%)$ & 4 & 4 & 4 & 4 \\
\hline Cashew bark exudate gum (\%) & 5.5 & 6 & 6.5 & 6.5 \\
\hline HPMC K4M (\%) & 2 & 2 & 2 & 2 \\
\hline Menthol (\%) & - & - & - & 0.1 \\
\hline Propylene glycol (\%) & 5 & 5 & 5 & 5 \\
\hline Methyl paraben (\%) & 0.02 & 0.02 & 0.02 & 0.02 \\
\hline Purified water q. s. (gm) & 10 & 10 & 10 & 10 \\
\hline
\end{tabular}

\section{Preparation of skin for ex vivo permeation experiment}

Excised porcine skin membrane was employed for the ex vivo permeation [2-3]. The porcine ear skin was collected from slaughterhouse after sacrificing the animal within $1 \mathrm{hr}$. The hair onto skin surface was taken out by means of a hair clipper and afterwards, the full thickness of the skin was collected. The fatty layers sticking to the dermis side of the skin was eradicated by means of a surgical scalpel. Finally, these excised porcine ear skin membranes were thoroughly cleaned through rinsing with distilled water and used.

\section{Ex vivo skin permeation experiment of $4 \%$ lidocaine $\mathrm{HCl}$ gels}

Ex vivo skin permeation of lidocaine from various formulated $4 \%$ lidocaine $\mathrm{HCl}$ gels and marketed $4 \%$ lidocaine $\mathrm{HCl}$ gel was performed by means of Franz diffusion cell. The Franz diffusion cell comprises 2 chambers: the donor chamber and the receptor chamber [22]. The diffusion area of the Franz diffusion cell was $0.79 \mathrm{~cm} 2$. The donor chamber was open at the top and was exposed to the atmosphere. The excised porcine ear skin membrane was mounted in between the chambers of the cell with stratum corneum facing the donor chamber and clamped into the position. A magnetic stirrer bar was fitted inside the receptor chamber, which was filled with phosphate buffer saline (PBS, pH 7.4) as receptor phase medium. A small concentration of sodium azide $(0.0025 \% \mathrm{w} / \mathrm{v})$ was put into the system to prevent the occurrence of microbial growth [30-31]. The whole system was positioned over a magnetic stirrer at $37 \pm 0.7{ }^{\circ} \mathrm{C}$. At the start, the skin membrane was left in the Franz diffusion cell for $2 \mathrm{~h}$ so as to make possible hydration of the skin membrane. After $2 \mathrm{~h}$ of hydration of the skin membrane, $1 \mathrm{gm}$ of $4 \%$ lidocaine $\mathrm{HCl}$ gels was applied onto the skin membrane surface. $1 \mathrm{ml}$ of receptor phase medium was collected from the receptor chamber at predetermined intervals and the same amount of fresh receptor phase medium was replaced to the receptor chamber. The amount of drug permeated through the excised porcine ear skin membrane was determined by means of a UV-VIS spectrophotometer (Shimadzu, Japan) at $274 \mathrm{~nm}$ of wavelength.

\section{Skin permeation data analysis}

\section{Permeation flux}

The drug amounts permeated through excised porcine ear skin membrane from various formulated $4 \%$ lidocaine $\mathrm{HCl}$ gels and marketed $4 \%$ lidocaine $\mathrm{HCl}$ gel were plotted against the function of time. The slopes of the linear portion of the plots were derived through regression analyses. The permeation fluxes were calculated as the slope divided by the surface area of skin membrane employed [32]:

$\mathrm{J}_{s s}=(\mathrm{dQ} / \mathrm{dt})_{s s} \cdot 1 / \mathrm{A}$, where $\mathrm{J}_{s s}$ is the steady state permeation flux $\left(\mu \mathrm{g} / \mathrm{cm}^{2} / \mathrm{hr}\right), A$ is the surface area of skin membrane employed $\left(\mathrm{cm}^{2}\right)$, and $(\mathrm{dQ} / \mathrm{dt})_{\mathrm{ss}}$ is the amount of drug permeated through the excised porcine ear skin membrane per unit time at a steady state $(\mu \mathrm{g} / \mathrm{hr})$.

\section{Kinetics}

The drug permeation data were assessed by means of some important mathematical models [33]: Zero order model: $\mathrm{F}=\mathrm{K}_{\mathrm{o}} \mathrm{t}$; First order model: $\ln (1-F)=-K_{1} t$; Higuchi model: $F=K_{H} t^{1 / 2}$ and Korsmeyer-Peppas model: $F=K_{p} t^{n}$, where $F=$ fraction of drug permeated in time $t, K_{0}=$ Zero order rate constant, $K_{1}=$ First order rate constant, $\mathrm{K}_{\mathrm{H}}=$ Higuchi model rate constant, $\mathrm{K}_{\mathrm{p}}=$ KorsmeyerPeppas model rate constant, and $\mathrm{n}=$ diffusion exponent.

\section{Stability testing}

Stability testing of formulated $4 \%$ lidocaine $\mathrm{HCl}$ gels was carried out using freeze-thaw cycling method [34]. The temperature of the study was varied every $24 \mathrm{~h}$ in between $25{ }^{\circ} \mathrm{C}$ and $-5{ }^{\circ} \mathrm{C}$ for complete 5 cycles. Gel samples were scrutinised for the physical stability and syneresis.

\section{Statistical analysis}

The data were analysed with simple statistics using Bio Stat version 2009 for Windows software, Analyst Soft Inc.

\section{RESULTS AND DISCUSSION}

\section{Preparation of $4 \%$ lidocaine $\mathrm{HCl}$ gels}

Lidocaine $\mathrm{HCl}(4 \%)$ gels were formulated by using different concentrations of cashew bark exudate gum along with HPMC K4M as a gelling agent. In these formulated $4 \%$ lidocaine $\mathrm{HCl}$ gels, methyl paraben and glycerine were added as preservative and plasticizer, respectively (table 1 ). These formulated $4 \%$ lidocaine $\mathrm{HCl}$ gels were assessed for $\mathrm{pH}$, viscosity, and ex vivo skin permeation of drug through excised porcine ear skin membrane.

\section{pH}

For a topical gel formulation, $\mathrm{pH}$ is important. The more acidic or basic $\mathrm{pH}$ of the topical formulations can change the skin 
environment, which can produce skin irritation upon application [22]. The $\mathrm{pH}$ of all these $4 \%$ lidocaine $\mathrm{HCl}$ gels containing cashew bark exudate gum was measured within the range of $6.04 \pm 0.02$ to $6.52 \pm 0.04$ (table 2), demonstrating that these gels were close to normal $\mathrm{pH}$ of the skin and can be used topically.

\section{Viscosity}

The viscosities of these formulated $4 \%$ lidocaine $\mathrm{HCl}$ gels containing cashew bark exudate gum were determined at $25 \pm 0.3{ }^{\circ} \mathrm{C}$, which ranges in between, $4.38 \pm 0.02 \times 10^{6}$ to $4.74 \pm 0.04 \times 10^{6} \mathrm{cps}$ (table 2). All these gels demonstrated a pseudoplastic flow (indicative of share thinning). This kind of rheology of these gels is ideal for topical formulations [34].

\section{Ex vivo permeation}

The formulated $4 \%$ lidocaine $\mathrm{HCl}$ gels containing cashew bark exudate gum and marketed topical gel formulation of $4 \%$ lidocaine $\mathrm{HCl}$ were evaluated for ex vivo permeation through excised porcine ear skin membrane. The ex vivo skin permeations of lidocaine from the formulated and marketed topical gels were observed to be sustained over a period of $7 \mathrm{~h}$ (fig. 1). The ex vivo skin permeation flux $\left(\mu \mathrm{g} / \mathrm{cm}^{2} / \mathrm{hr}\right)$ values for all these topical gels through the excised porcine ear skin membrane were shown in table 3 . The results of $e x$ vivo skin permeation experiment of $4 \%$ lidocaine $\mathrm{HCl}$ gels illustrated permeation fluxes within the range, $836.42 \pm 10.78$ to $1538.38 \pm 14.03$ $\mu \mathrm{g} / \mathrm{cm}^{2} / \mathrm{hr}$. The permeation flux values were found to be increased with the increment of HPMC K4M amounts within the gel formula.

Table 2: pHs and viscosities of $4 \%$ lidocaine HCl topical gels*

\begin{tabular}{|c|c|c|c|c|}
\hline & \multicolumn{4}{|c|}{ Formulation codes } \\
\hline & G1 & G2 & G3 & G4 \\
\hline $\mathrm{pH}$ & $6.04 \pm 0.02$ & $6.24 \pm 0.04$ & $6.52 \pm 0.04$ & $6.48 \pm 0.03$ \\
\hline Viscosity $\times 10^{6}$ (cps) & $4.38 \pm 0.02$ & $4.59 \pm 0.04$ & $4.70 \pm 0.04$ & $4.74 \pm 0.04$ \\
\hline
\end{tabular}

$*($ mean \pm standard error, $\mathrm{n}=3)$

Highest ex vivo permeation flux $\left(1538.38 \pm 13.77 \mu \mathrm{g} / \mathrm{cm}^{2} / \mathrm{hr}\right)$ was measured in the case of G4 gel containing $0.1 \%$ menthol as a permeation enhancer. $1422.18 \pm 12.76 \mu \mathrm{g} / \mathrm{cm}^{2} / \mathrm{hr}$ of ex vivo permeation flux was measured for the marketed topical gel of $4 \%$ lidocaine $\mathrm{HCl}$, which was higher than G3 gel and lower than G4 gel (containing $0.1 \%$ menthol). Menthol (a permeation enhancer terpene derivative) has long been employed as an effective permeation enhancer in numerous topical gels $[8,35]$. The skin permeation enhancers are the materials aiding absorption of drugs across the skin barrier through raising the permeability of the skin, temporarily. The skin permeation enhancers are mainly working through one or more of these 3 mechanisms: (a) improved partition of drug or solvent into stratum corneum, (b) disruption of the highly-ordered stratum corneum lipid structure and (c) interaction with the intracellular-proteins [35]. As skin permeation enhancer, menthol preferentially distributes into the intercellular spaces of the stratum corneum [36]. In addition, menthol perhaps produces reversible disruption of lipid domains of the stratum corneum and thus, enhances the permeation of drugs through the skin [22].

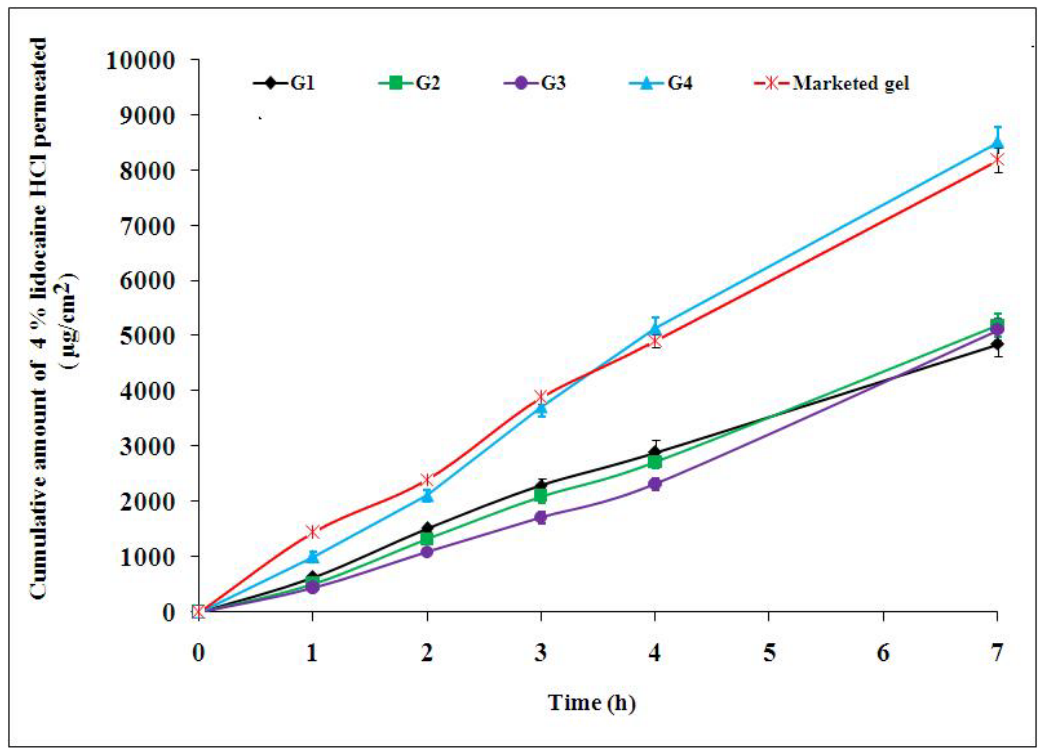

Fig. 1: Ex vivo permeation profile through excised porcine ear skin membrane per unit area from $4 \%$ lidocaine $\mathrm{HCl}$ topical gels (mean \pm standard error, $n=3$ )

Table 3: Ex vivo permeation fluxes $\left(\mathrm{J}, \mu \mathrm{g} / \mathrm{cm}^{2} / \mathrm{h}\right)$ of $4 \%$ lidocaine $\mathrm{HCl}$ topical gels

\begin{tabular}{ll}
\hline Formulation code & Permeation flux $\left.\mathbf{( J , ~} \mathbf{\mu g} / \mathbf{c m}^{2} / \mathbf{h}\right)^{*}$ \\
\hline G1 & $836.42 \pm 10.78$ \\
G2 & $992.76 \pm 9.12$ \\
G3 & $1236.08 \pm 11.70$ \\
G4 & $1538.38 \pm 13.77$ \\
Marketed gel & $1422.18 \pm 12.76$ \\
\hline
\end{tabular}

*(mean \pm standard error, $\mathrm{n}=3)$ 
The results of ex vivo skin permeation from formulated topical gels containing cashew bark exudate gum and marketed topical gel of 4 $\%$ lidocaine $\mathrm{HCl}$ through excised porcine ear skin membrane were kinetically evaluated and analyzed using various kinetic models: zero order, first order, Higuchi, and Korsmeyer-Peppas model (table 4). When the respective correlation coefficients $\left(\mathrm{R}^{2}\right)$ were compared, Korsmeyer-Peppas model was found as a best-fit model $\left(R^{2}=0.9957\right.$ to 0.9982 ) over a period of $7 \mathrm{~h}$. Besides, zero order model was also found to be almost closer to the best-fit Korsmeyer-Peppas model. Again, the Korsmeyer-Peppas model was employed in the ex vivo lidocaine $\mathrm{HCl}$ skin permeation behavior analysis of these formulations: Fickian (nonsteady) when $n \leq 0.5$, case-II transport (zero order) when $n \geq 1$, and non-Fickian (anomalous) when the value of $\mathrm{n}$ is in between 0.5 and 1 [30-31]. The calculated diffusion exponent $(n)$ values of formulated $4 \%$ lidocaine $\mathrm{HCl}$ topical gels containing cashew bark exudate gum (G1 to G4) were ranged within 0.95 and 1.12 (table 4). On the other hand, $\mathrm{n}$ value of 0.88 was calculated for the marketed topical gel of $4 \%$ lidocaine $\mathrm{HCl}$. These results indicated that the ex vivo lidocaine $\mathrm{HCl}$ skin permeation from these formulated $4 \%$ lidocaine $\mathrm{HCl}$ topical gels containing cashew bark exudate gum (G1 to G4) followed the super case-II transport mechanism.

Table 4: Curve fitting results of the ex vivo skin permeation of $4 \%$ lidocaine $\mathrm{HCl}$ topical gels

\begin{tabular}{llllll}
\hline Formulation code & G1 & G2 & G3 & G4 & Marketed gel \\
\hline Zero order model & 0.9886 & 0.9903 & 0.9907 & 0.9889 \\
First order model & 0.8846 & 0.9013 & 0.9643 & 0.8607 \\
Higuchi model & 0.7814 & 0.6539 & 0.5715 & 0.6524 \\
Korsmeyer-Peppas model & 0.9963 & 0.9957 & 0.9968 & 0.9960 \\
n (diffusion exponent) & 0.95 & 1.08 & 1.17 & 0.7844 & 0.9982 \\
\hline
\end{tabular}

\section{Stability}

The stability of the formulated $4 \%$ lidocaine $\mathrm{HCl}$ topical gels containing cashew bark exudate gum (G1 to G4) was determined by freeze thaw cycling method. The stability study by freeze thaw cycling revealed that these formulated topical gels were physically stable. However, syneresis (spontaneous contraction of gel exuding some of the fluid medium) was not observed, even after completion of 5 complete freeze thaw cycling.

\section{CONCLUSION}

$4 \%$ lidocaine $\mathrm{HCl}$ topical gels were prepared by using different concentrations of cashew bark exudate gum, HPMC K4M, lidocaine $\mathrm{HCl}$, methyl paraben (as a preservative) and glycerin (as plasticizer). The $\mathrm{pH}$ of these formulated topical gels (G1 to G4) was found within the range of $6.04 \pm 0.02$ to $6.52 \pm 0.04$ and the viscosity was found in between $4.38 \pm 0.02 \times 10^{6}$ to $4.74 \pm 0.04 \times 10^{6} \mathrm{cps}$. These topical gels demonstrated sustained ex vivo permeation through excised porcine ear skin membrane of lidocaine $\mathrm{HCl}$ over a period of $7 \mathrm{~h}$ using Franz diffusion cell. The ex vivo skin permeation fluxes of these $4 \%$ lidocaine $\mathrm{HCl}$ topical gels containing cashew bark exudate gum ranged $836.42 \pm 10.78$ to $1538.38 \pm 14.03 \mu \mathrm{g} / \mathrm{cm}^{2} / \mathrm{hr}$. Highest ex vivo permeation flux $\left(1538.38 \pm 13.77 \mu \mathrm{g} / \mathrm{cm}^{2} / \mathrm{hr}\right)$ was measured in the case of G4 gel containing $0.1 \%$ menthol as a permeation enhancer.

These formulated topical gels (G1 to G4) found to be best-fit with Korsmeyer-Peppas model $\left(\mathrm{R}^{2}=0.9957\right.$ to 0.9982$)$ with super case-II transport mechanism over a period of $7 \mathrm{~h}$. The stability study revealed that these $4 \%$ lidocaine $\mathrm{HCl}$ topical gels containing cashew bark exudate gum were physically stable. Even after completion of 5 complete freeze thaw cycling, any sign of syneresis was absent in these topical gels.

\section{ACKNOWLEDGEMENT}

The authors would like to acknowledge the financial assistance provided by University Grant Commission, New Delhi, India under Maulana Azad National Fellowship for minority students as well as Shri Venkateshwara University, Gajraula, U. P, India for providing the research facility.

\section{AUTHORS CONTRIBUTION}

All authors of the current manuscript contributed equally.

\section{CONFLICT OF INTERESTS}

Declared none

\section{REFERENCES}

1. Khatri SK, Rathnanand M. Formulation and evaluation of wound healing activity of linezolid topical preparations on diabetic rats. Int J Appl Pharm 2016;8:30-6.
2. Das B, Sen So, Maji R, Nayak AK, Sen KK. Transferosomal gel for transdermal delivery of risperidone. J Drug Delivery Sci Technol 2017;38:59-71.

3. Malakar J, Basu A, Nayak AK. Candesartan cilexetil microemulsions for transdermal delivery: formulation, in vitro skin permeation and stability assessment. Curr Drug Delivery 2014;11:313-21.

4. Das S, Samanta A, Bose A. Design, development and evaluation of fluconazole topical gels. Asian J Pharm Clin Res 2015;8:199-206.

5. Kaur D, Raina A, Singh N. Formulation and evaluation of Carbopol 940 based glibenclamide transdermal gel. Int J Pharm Pharm Sci 2014;6:434-40.

6. Jana S, Ali SA, Nayak AK, Sen KK, Basu SK. Development and optimisation of a topical gel containing aceclofenaccrospovidone solid dispersion by "Quality by Design" approach. Chem Eng Res Des 2014;92:2095-105.

7. Verma A. Formulation and evaluation of clobetasol proprionate gel. Asian J Pharm Clin Res 2013;6:15-8.

8. Nayak AK, Mohanty B, Sen KK. Comparative evaluation of in vitro diclofenac sodium permeability across excised mouse skin from different common pharmaceutical vehicles. Int J PharmTech Res 2010;2:920-30.

9. Jana S, Manna S, Nayak AK, Sen KK, Basu SK. Carbopol gel containing chitosan-egg albumin nanoparticles for transdermal aceclofenac delivery. Colloids Surf B 2014;114;36-44.

10. Abdelgawad R, Nasr M, Hamza MY, Awad GAS. Topical and systemic dermal carriers for psoriasis. Int J Curr Pharm Res 2016;8:4-9.

11. Pithayanukul $P$, Chansri N, Sugibayashi K. The enhancing effects of common pharmaceutical solvents on the in vitro skin permeation of estradiol. Thai J Pharm Sci 2002;26:109-19.

12. Reiz GME, Reiz SL. EMLA-a eutectic mixture of local anaesthetics for topical anaesthesia. Acta Anaesthesiol Scand 1982;26:596-8.

13. Wang Y, Su W, Li Q, Li C, Wang H, Li Y, et al. Preparation and evaluation of lidocaine hydrochloride-loaded TAT-conjugated polymeric liposomes for transdermal delivery. Int J Pharm 2013;441:748-56

14. Trotta M, Peira E, Debernardi F, Gallarate M. Elastic liposomes for skin delivery of dipotassium glycyrrhizinate. Int J Pharm 2002;241:319-27.

15. Smith DW, Peterson MR, DeBerard SC. Regional anaesthesia. Nerve blocks of the extremities and face. Postgrad Med 1999;106:57-60.

16. Lee PJ, Ahamad N, Langer R, Mitragotri S, Shastri VP. Evaluation of chemical enhancers in the transdermal delivery of lidocaine. Int J Pharm 2006;308:33-9.

17. Sarpotdar PP, Zatz JL. Evaluation of penetration enhancement of lidocaine by nonionic surfactants through hairless mouse skin in vitro. J Pharm Sci 1986;75:176-81.

18. Shin SC, Cho CW, Yang KH. Development of lidocaine gels for enhanced local anesthetic action. Int J Pharm 2004;287:73-8. 
19. Mueller-Goymann CC, Frank SG. Interaction of lidocaine and lidocaine-HCl with liquid crystal structure of topical preparations. Int J Pharm 1986;29:147-59.

20. Padula C, S Nicoli S, Colombo P, Santi P. Single-layer transdermal film containing lidocaine: modulation of drug release. Eur J Pharm Biopharm 2007;66:422-8.

21. Rowbotham MC, Davies PS, Fields HL. Topical lidocaine gel reduces pain in post-herpetic neuralgia. Ann Neurol 1995; 37:246-53.

22. Das B, Nayak AK, Nanda U. Topical gels of lidocaine $\mathrm{HCl}$ using cashew gum and Carbopol 940:Preparation and in vitro skin permeation. Int J Biol Macromol 2013;62:514-7.

23. De Paula RCM, Rodrigues JF. Composition and rheological properties of cashew tree gum, the exudate polysaccharide from Anacardium occidentale L. Carbohydr Polym 1995;26:177-81.

24. Das B, Dutta S, Nayak AK, Nanda U. Zinc alginate-carboxymethyl cashew gum micro beads for prolonged drug release: development and optimization. Int J Biol Macromol 2014;70:505-15.

25. Silva DA, de Paula RCM, Feitosa JPA, de Brito ACF, Maciel JS, Paula HCB. Carboxymethylation of cashew tree exudate polysaccharide. Carbohydr Polym 2004;58:163-71.

26. Silva DA, Feitosa JPA, Maciel JS, Paula HCB, de Paula RCM Characterization of crosslinked cashew gum derivatives. Carbohydr Polym 2006;66:16-26.

27. Gowthamarajan K, Phani Kumar GK, Gaikward NB, Suresh B Preliminary study of Anacardium occidentale gum as a binder in the formulation of paracetamol tablets. Carbohydr Polym 2011;83:506-11.

28. Gowthamarajan $\mathrm{K}$, Jawahar $\mathrm{N}$, Wake $\mathrm{P}$, Jain $\mathrm{K}$, Sood $\mathrm{S}$ Development of buccal tablets for curcumin using Anacardium occidentale gum. Carbohydr Polym 2012;88:1177-83.
29. Kumar R, Patil MB, Patil SR, Paschapur MS. Evaluation of Anacardium occidentale gum as gelling agent in aceclofenac gel. Int J PharmTech Res 2009;1:695-704.

30. Malakar J, Sen SO, Nayak AK, Sen KK. Development and evaluation of microemulsions for transdermal delivery of insulin. ISRN Pharm 2011. http://dx.doi.org/10.5402/ $2011 / 780150$

31. Malakar J, Nayak AK, Basu A. Ondansetron $\mathrm{HCl}$ microemulsions for transdermal delivery: Formulation and in vitro evaluation. ISRN Pharm 2012. http://dx.doi.org/10.5402/2012/428396

32. Rath Adhikari SN, Nayak BS, Nayak AK, Mohanty B. Formulation and evaluation of buccal patches for delivery of atenolol. AAPS PharmSciTech 2010;11:1034-44.

33. Malakar J, Sen SO, Nayak AK, Sen KK. Formulation, optimisation and evaluation of transpersonal gel for transdermal insulin delivery. Saudi Pharm J 2012;20:355-63.

34. Panda D, Si S, Swain S, Kanungo SK, Gupta R. Preparation and evaluation of gels from the gum of Moringa oleifera. Indian Pharm Sci 2006;68:777-80.

35. Pathan IB, Setty CM. Chemical penetration enhancers for transdermal drug delivery systems. Trop J Pharm Res 2009;8:173-9.

36. Jain AK, Thomas NS, Panchangnula R. Transdermal drug delivery of imipramine hydrochloride. I. Effect of terpenes. J Controlled Release 2002;79:93-101.

\section{How to cite this article}

- M Saquib Hasnain, Poonam Rishishwar, Sadath Ali. Use of cashew bark exudate gum in the preparation of $4 \%$ lidocaine HCL topical gels. Int J Pharm Pharm Sci 2017;9(8):146-150. 